\title{
Extraction of Alumina from Red Mud for Synthesis of Mesoporous Alumina by Adding CTABr as Mesoporous Directing Agent
}

\author{
Eka Putra Ramdhani ${ }^{1,2}$, Tri Wahyuni', Yatim Lailun Ni'mah', \\ Suprapto ${ }^{1}$, and Didik Prasetyoko ${ }^{1, *}$ \\ ${ }^{1}$ Department of Chemistry, Faculty of Mathematics and Natural Sciences, Institut Teknologi Sepuluh Nopember, \\ Keputih, Sukolilo, Surabaya 60111, Indonesia \\ ${ }^{2}$ Department of Chemistry Education, Faculty of Teacher Training and Education, Raja Ali Haji Maritime University, \\ Senggarang, Tanjungpinang, Indonesia
}

Received May 19, 2017; Accepted November 23, 2017

\begin{abstract}
Mines in Bintan were producing bauxite for many years. The production process of bauxite to alumina produced much red mud. From X-ray Fluorescence (XRF), alumina content on Bintan's red mud was 28.87 wt.\%. This research was studying on the extraction alumina from red mud with reduction of hematite $\left(\mathrm{Fe}_{2} \mathrm{O}_{3}\right)$ and desilication processes. After extraction process alumina was collected about $52.89 \mathrm{wt} . \%$. Synthesis of mesoporous alumina from red mud using sol-gel method at the room temperature for $72 \mathrm{~h}$ with cetyltrimethylammonium bromide (CTABr) as mesoporous directing agent. The CTABr/Al-salt ratio, i.e. 1.57; 4.71 and 7.85 with the sample code of $A M C-1, A M C-3, A M C-5$, respectively. The product was calcined at $550{ }^{\circ} \mathrm{C}$ for $6 \mathrm{~h}$. The synthesized materials were characterized by X-ray Diffraction (XRD), scanning electron microscopy-energy dispersive X-ray (SEM-EDX), transmission electron microscopy (TEM), and $N_{2}$ adsorption-desorption techniques. XRD pattern of AMC-1, AMC-3, and $A M C-5$ showed that all synthesized materials have amorphous phase. The morphology were wormhole aggregate that were showed by SEM and TEM characterization. $\mathrm{N}_{2}$ adsorption-desorption characterization showed the distribution of pore size of about $3.2 \mathrm{~nm}$. The highest surface area and pore volume were obtained in solid-solid ratio CTABr/GM-AL by 1.57 (AMC-1) i.e. $241 \mathrm{~m}^{2} / \mathrm{g}$ and $0.107 \mathrm{~cm}^{3} / \mathrm{g}$, respectively.
\end{abstract}

Keywords: red mud; CTABr; alumina extraction; sol-gel method; mesoporous alumina

\section{ABSTRAK}

Pertambangan di Bintan telah memproduksi bauksit selama bertahun-tahun. Proses produksi dari bauksit menjadi alumina menghasilkan banyak red mud. Berdasarkan data X-Ray Fluorescence (XRF), kandungan alumina pada red mud dari Bintan adalah 28,87\%. Penelitian ini mempelajari pemisahan hematite $\left(\mathrm{Fe}_{2} \mathrm{O}_{3}\right)$ dari red mud dan proses desilikasi. Hasil proses ekstraksi alumina dari red mud diperoleh kandungan alumina sebesar 52,89\%. Sintesis alumina mesopori dari red mud menggunakan metode sol-gel pada suhu ruang selama 72 jam dengan menambahkan cetyltrimethylammonium bromide (CTABr). Parameter sintesis yang digunakan adalah perbandingan dari CTABr/GM-AL yaitu 1,57; 4,71 dan 7,85 dengan kode sampel of AMC-1, AMC-3, AMC-5. Produk sintesis dikalsinasi pada $550{ }^{\circ} \mathrm{C}$ selama 6 jam. Alumina mesopori kemudian dikarakterisasi menggunakan XRD, scanning electron microscopy-energy dispersive X-Ray analysis (SEM-EDX), transmission electron microscopy (TEM), dan $\mathrm{N}_{2}$ adsorption-desorption. Hasil karakterisasi menggunakan X-Ray Diffraction (XRD) menunjukkan AMC-1, AMC-3, AMC-5 memiliki fase amorf dan memiliki bentuk seperti lubang cacing yang dapat dilihat dari karakterisasi menggunakan SEM and TEM. Karakterisasi $\mathrm{N}_{2}$ adsorption-desorption menunjukkan distribusi ukuran pori pada ukuran 3,2 nm. Luas permukaan dan volume pori terbesar diperoleh dengan rasio CTABr/GM-AL 1,57 (AMC-1) dengan $241 \mathrm{~m}^{2} / \mathrm{g}$ dan $0,107 \mathrm{~cm}^{3} / \mathrm{g}$.

Kata Kunci: red mud; CTABr; ektraksi alumina; metode sol-gel; alumina mesopori

\section{INTRODUCTION}

Red mud is the solid waste generated from the alumina refining of bauxite ore, primarily by the Bayer process which utilizes caustic soda to dissolve the aluminosilicates. The production of 1 tons alumina generates 1-1.5 tons red mud [1]. The generation of red mud is estimated to be 4 billion tons by 2015 based upon its current rate of production [2].

* Corresponding author.

Email address : didikp@chem.its.ac.id

DOI: $10.22146 /$ ijc.25108

Eka Putra Ramdhani et al. 
Issues of red mud were going to be a global concern confronting the alumina industries because of harmful impact from resulting disposal. The disposal of red mud remains a complicated issues because of its high alkalinity $(\mathrm{pH} 10-13)$ [3] and the very large quantities generated. Disposal methods have been applied including landfill, deep sea dumping, and storage in settling ponds. These methods give harmful impact on our environment [4]. Many attempts have been made to find a sustainable process and cost effective method to dispose of red mud [5]. Several methods have focused on the utilization option for red mud, including: as adsorbent for pollutant removal [6], building materials (such as brick, concrete, cement and road foundation materials) [7], ceramic [8], adsorbents [9], coagulants [10], catalyst [11-12], as agent for neutralizing acidic waste [13]. The utilization of red mud as source of alumina to synthesize mesoporous alumina not investigated yet.

Red mud could be also regarded as a resource of multiple metals. The main compositions of red mud are $\mathrm{Fe}_{2} \mathrm{O}_{3} 14-45 \%, \mathrm{Al}_{2} \mathrm{O}_{3} 5-14 \%, \mathrm{SiO}_{2} 1-9 \%, \mathrm{Na}_{2} \mathrm{O} 1-6 \%$, $\mathrm{TiO}_{2} 2-12 \%$ [14]. The main minerals used for iron include magnetite $\left(\mathrm{Fe}_{3} \mathrm{O}_{4}\right)$, hematite $\left(\mathrm{Fe}_{2} \mathrm{O}_{3}\right)$, goethite $(\mathrm{FeO}(\mathrm{OH}))$, siderite $\left(\mathrm{FeCO}_{3}\right)$, pyrite $\left(\mathrm{FeS}_{2}\right)$. Hematite and goethite are the major constituents of red mud. Magnetic separation is a basic method for iron recovery from red mud. The resulting magnetic product can then be used as an ingredient for iron production and the nonmagnetic portion can be used in building materials [15]. However, direct magnetic separation was inefficient because of the dissemination of fine iron oxides. The alumina was remained in red mud residue. The alumina is either extracted using organic or inorganic acid. Sulfuric, citric and oxalic acid have been used to extract Al from red mud [16]. A mixture of 2:1 citric and oxalic acids dissolved $96 \% \mathrm{Al}$ in the red mud.

This research investigated about extraction of alumina from red mud as the source of alumina using leaching method with chloride acid to synthesize mesoporous alumina. Before these process, direct magnetic separation was used to reduce of iron. Alumina source from red mud was added with CTABr to form mesoporous alumina. The amount of $\mathrm{CTABr}$ was varied to investigate the change of mesoporous alumina characteristics. The synthesis of mesoporous alumina was carried out at the room temperature and calcined at $550^{\circ} \mathrm{C}$ for $6 \mathrm{~h}$.

\section{EXPERIMENTAL SECTION}

\section{Materials}

The materials used in this experiment were red mud (from Bintan, Riau Island, Indonesia), chloride acid
$(\mathrm{HCl}$, Merck, 37\%), sodium hydroxide $(\mathrm{NaOH}$, Merck, 99.5\%); Cetyltrimethylammonium bromide (CTABr, $\mathrm{C}_{19} \mathrm{H}_{42} \mathrm{BrN}$, Merck, 99\%); and deionized water.

\section{Instrumentation}

X-Ray Fluorescence (XRF, Shimadzu) determines the composition of red mud, X-Ray Diffraction (XRD Philips Expert) using $\mathrm{Cu}$ Ka radiation $(40 \mathrm{kV}, 30 \mathrm{~mA})$ to identify the mineral phase, Inductively Coupled Plasma (ICP Prodigy) to analyze the content of aluminum, Scanning Electron Microscope - Energy Dispersive X-Ray (SEM ZEISS EVO MA 10 using a $30 \mathrm{kV}$ and EDX BRUKER $129 \mathrm{EV}$ ) to know the morphology of sample. Total surface area, pore size distribution and total pore volume were determined from $\mathrm{N}_{2}$ adsorption-desorption using a Quantachrome Instruments Nova 1200. Total surface area was determined by the BET and pore size distribution and volume in the mesoporous were determined from the BJH method. For TEM images, high resolution images and selected area electron diffraction patterns were recorded using a JEM 1400 instrument operating at $120 \mathrm{kV}$.

\section{Procedure}

\section{Determination of Lost of Ignition (LOI)}

The red mud was crushed to the required particle size (200 mesh) and dried at $110^{\circ} \mathrm{C}$ for $1 \mathrm{~h}$ to remove water content. Red mud $(1.8 \mathrm{~g})$ was placed into crucible and roasted at $1050{ }^{\circ} \mathrm{C}$ for $1 \mathrm{~h}$. Roasted sample was placed into desiccators for $5 \mathrm{~min}$, weighing up and calculated of LOI content by using eq. 1 :

$\operatorname{LOI}($ wt.\% $)=\frac{100 \times\left(\mathrm{n}_{2}-\mathrm{n}_{3}\right)}{\left(\mathrm{n}_{2}-\mathrm{n}_{1}\right)}$

which, $n_{1}$ is weight of crucible, $n_{2}$ is weight of crucible and red mud before fusion process, $n_{3}$ is weight of crucible and red mud after fusion process.

\section{Separation of iron $\left(\mathrm{Fe}_{2} \mathrm{O}_{3}\right)$}

Iron was separated from red mud by magnetic separation method. Red mud was placed into beaker glass for $50 \mathrm{~g}$ in $1 \mathrm{~L}$ water. The mixture stirred for $24 \mathrm{~h}$ using a magnetic bar at low speed. Solid from this process were collected for the next process.

\section{Extraction of alumina from red mud}

The solid from magnetic separation process was placed into beaker glass and dissolve with hydrochloride acid $(\mathrm{HCl})$ solution $6 \mathrm{~N}$ (composition ratio solid : chloride acid $(\mathrm{HCl})$ solution was $1: 5 \mathrm{~g} / \mathrm{mL}$ ) and stirred for $2 \mathrm{~h}$ at $90^{\circ} \mathrm{C}$. The mixture was filtered. Filtrate was dissolved with $\mathrm{NaOH} 5 \mathrm{~N}$ solution and stirred until 
$\mathrm{NaAlO}_{2}$ had formed and then filtered. Collected $\mathrm{NaAlO}_{2}$ was dissolved with $\mathrm{HCl} 6 \mathrm{~N}$ and stirred until $\mathrm{pH}$ 7. The $\mathrm{NaAlO}_{2}$ solid was washed using deionized water.

\section{Synthesis of Mesoporous Alumina}

A Mixture of $\mathrm{NaAlO}_{2}(7.5 \mathrm{~g})$ and variation of $\mathrm{CTABr}$ solution $(1,3,5 \mathrm{~g} \mathrm{CTABr}$ was dissolved to $50 \mathrm{~mL}$ aquadest at $60^{\circ} \mathrm{C}$ ), and stirred for $1 \mathrm{~h}$. The mixture was aged for $72 \mathrm{~h}$ at the room temperature. The product was washed by deionized water and dried at $120{ }^{\circ} \mathrm{C}$. The addition of $\mathrm{CTABr}$ was used as template to form mesopores structure. Thus, template will disappeared and formed porous structure after calcination process at $550{ }^{\circ} \mathrm{C}$ for $6 \mathrm{~h}$. the synthesized product then analyzed with XRD, $\mathrm{N}_{2}$ Adsorption Desorption, SEM-EDX, and TEM.

\section{RESULT AND DISCUSSION}

\section{XRF (X-Ray Fluorescence)}

Red mud has different compositions at different area according to the separated process that use to produce alumina. The content of Bintan's red mud is primarily as $\mathrm{Fe}_{2} \mathrm{O}_{3} 44.66 \%, \mathrm{Al}_{2} \mathrm{O}_{3} 28.87 \%, \mathrm{SiO}_{2} 20.21 \%$ (Table 1). These result showed that $\mathrm{Fe}_{2} \mathrm{O}_{3}$ was major component in red mud. Therefore, before synthesis process, $\mathrm{Fe}_{2} \mathrm{O}_{3}$ was separated by direct magnetic separation. The product from direct magnetic separation was characterized by XRF. The content of $\mathrm{Fe}_{2} \mathrm{O}_{3}$ be $44.81 \%$ (seen in Table 1) indicated that direct magnetic separation at this study had not influenced as significant on the content of $\mathrm{Fe}_{2} \mathrm{O}_{3}$. It could be happened because of almost $\mathrm{Fe}_{2} \mathrm{O}_{3}$ in samples was hematite that couldn't be attracted by magnet.

The product from magnetic separation was used to leaching process. A mixture of solid and $\mathrm{HCl} 6 \mathrm{~N}$ solution (ratio of solid/solution $1: 5 \mathrm{~g} / \mathrm{mL}$ ) was heated at the temperature of $90{ }^{\circ} \mathrm{C}$ for $2 \mathrm{~h}$ to dissolve alumina $\left(\mathrm{Al}_{2} \mathrm{O}_{3}\right)$ from red mud. After this process, $\mathrm{SiO}_{2}$ was separated with filtration. The residual (solid) was characterized by $\mathrm{XRF}$ and the filtrate was used to the next process. The result from XRF showed that the major composition on residual solid consist of $38.85 \% \mathrm{SiO}_{2}$ (shown in Table 1).
$\mathrm{SiO}_{2}$ content on red mud was increased from $20.21 \%$ in red mud to $38.85 \%$ in residual solid after leaching process, it indicated that much of silica can separated from red mud with leaching process.

The next step was precipitation of alumina by using $5 \mathrm{~N} \mathrm{NaOH}$ solution. After filtration, residual solid was characterized by XRF and XRD whereas filtrate was used to the next step. The result from XRF showed residual solid (RME) contained of $\mathrm{Fe}_{2} \mathrm{O}_{3}$ $81.80 \%$ (shown in Table 1) and other impurities $(\mathrm{NaCl})$. But no $\mathrm{SiO}_{2}$ and $\mathrm{Al}_{2} \mathrm{O}_{3}$ were found in residual solid from this process. It indicated that the isolation process of $\mathrm{Fe}_{2} \mathrm{O}_{3}$ from red mud was succeed.

\section{XRD (X-Ray Diffraction)}

The XRD pattern of red mud (RM) and residual solid from this study showed at Fig. 1. The XRD pattern (Fig. 1) (a) showed of red mud. Red mud consist of hematite $\left(\mathrm{Fe}_{2} \mathrm{O}_{3}\right)$, gibbsite $\left(\mathrm{Al}(\mathrm{OH})_{3}\right)$, boehmite $(\mathrm{y}-\mathrm{AlO}(\mathrm{OH}))$, anatase $\left(\mathrm{TiO}_{2}\right)$ and quartz $\left(\mathrm{SiO}_{2}\right)$. These result, according with XRD pattern of hematite at $2 \theta=$ $26^{\circ}, 40^{\circ}, 47^{\circ}, 58^{\circ}, 64^{\circ}$; gibbsite at $2 \theta=20^{\circ}, 24^{\circ}$; boehmite at $2 \theta=18^{\circ}, 33^{\circ}, 45^{\circ}, 58^{\circ}$; anatase at $2 \theta=$ $28^{\circ}, 55^{\circ}$; quartz at $2 \theta=21^{\circ}, 26^{\circ}$, and $50^{\circ}$ [17]. Fig. 1 (b) showed XRD pattern of red mud from magnetic separation (RMS) have hematite and gibbsite phase. These result indicated that magnetic separation method

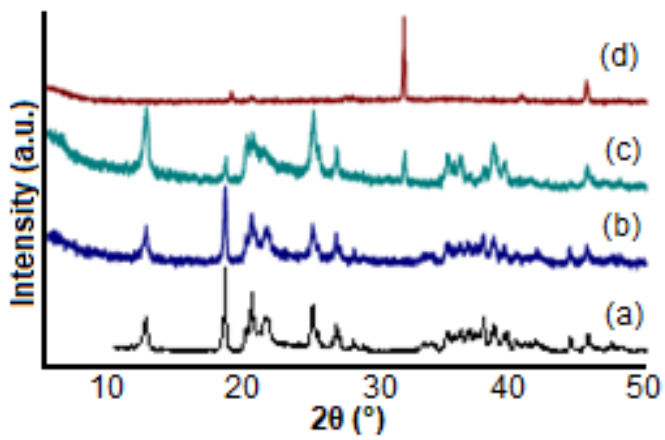

Fig 1. XRD pattern of (a) red mud (RM), (b) red mud from magnetic separation (RMS), (c) residue from leaching process (RMD), (d) residue from extraction process

Table 1. Chemical composition (contents-wt.\%) of red mud (RM)

\begin{tabular}{|c|c|c|c|c|c|c|c|c|c|c|c|c|}
\hline Sampl & $\mathrm{Fe}_{2} \mathrm{O}_{3}$ & $\mathrm{Al}_{2} \mathrm{O}_{3}$ & $\mathrm{SiO}_{2}$ & $\mathrm{TiO}_{2}$ & $\mathrm{ZrO}_{2}$ & $\mathrm{NiO}$ & $\mathrm{P}_{2} \mathrm{O}_{5}$ & $\mathrm{~K}_{2} \mathrm{O}$ & $\mathrm{CaO}$ & $\mathrm{Cr}_{2} \mathrm{O}_{3}$ & $\mathrm{NaCl}$ & $\mathrm{LOI}^{\mathrm{a}}$ \\
\hline $\mathrm{RM}$ & 44.66 & 28.87 & 20.21 & 3.03 & 1.29 & 0.62 & 0.51 & 0.37 & 0.28 & 0.10 & & 20.59 \\
\hline RMS & 44.81 & 30.15 & 20.60 & 2.99 & 0.12 & 0.12 & 0.53 & 0.35 & 0.28 & 0.09 & & \\
\hline RMD & 20.56 & 27.90 & 38.85 & 8.36 & 2.89 & & & 1.45 & & & & \\
\hline RME & 81.80 & & & & & & & & & & 18.19 & \\
\hline áOI & st on ignition & & & & & & & & & & & \\
\hline $\mathrm{RM}$ & : red mud & & & & & & & & & & & \\
\hline RMS & red mud from $\mathrm{m}$ & Iagnetic & ation & & & & & & & & & \\
\hline RMD & : residual solid a & ter leac & & & & & & & & & & \\
\hline RME & : residual solid & rex & proce & & & & & & & & & \\
\hline
\end{tabular}


was not effective to reduce hematite and another impurities in the red mud. Fig. 1(c) showed XRD pattern of red mud from leaching process which the diffraction pattern quartz at $2 \theta=20^{\circ}, 26^{\circ}$. It indicated that quartz had been reduced from red mud successfully. This result was supported by XRF that composition of silica on red mud residue about $38.85 \%$. Fig. 1(d) showed XRD pattern of red mud from extraction process which the diffraction pattern of halite $(\mathrm{NaCl})$ at $2 \theta=32^{\circ}, 45^{\circ}$. XRD pattern showed that $\mathrm{Fe}(\mathrm{OH})_{3}$ was formed which showed at amorphous phase [18]. The result was supported by XRF analysis that showed $\mathrm{Fe}_{2} \mathrm{O}_{3}$ on residue $81.80 \%$. It indicated that $\mathrm{Fe}_{2} \mathrm{O}_{3}$ was separated from red mud.

Fig. 2 showed XRD pattern of alumina salt and mesoporous alumina. Fig. 2(a) showed of alumina salt that have amorphous form. Fig. 2(b) showed $\mathrm{y}-\mathrm{Al}_{2} \mathrm{O}_{3}$ as a comparison to alumina salt. The diffraction pattern of $\mathrm{Y}-\mathrm{Al}_{2} \mathrm{O}_{3}$ showed crystalline phase which peak of diffraction at $2 \theta=15^{\circ}, 18^{\circ}, 20^{\circ}, 26^{\circ}, 30^{\circ}, 31^{\circ}, 35^{\circ}$ [19]. Fig. 2(c-e) showed of mesoporous alumina with variation of CTABr added which $1 \mathrm{~g}$ (c), $3 \mathrm{~g}(\mathrm{~d}), 5 \mathrm{~g}$ (e). The purpose of adding $\mathrm{CTABr}$ to alumina was to form mesoporous with low crystallinity. The XRD pattern showed that amorphous phase was formed (Fig. 2(c-d)) [20].

\section{SEM Images and EDX}

Fig. 3 showed SEM images for alumina salt and mesoporous alumina. SEM characterization showed morphology and determined the particle size of mesoporous alumina. Fig. 3(a) showed that alumina salt has disordered morphology and there was no pore seen in the surface. Fig. 3(b-c) showed morphology of mesoporous alumina with addition of $\operatorname{CTABr}(1,3,5 \mathrm{~g})$ like a disordered wadding. The added of CTABr with a different concentration had influenced the morphology of alumina particle.

EDX analysis for mesoporous alumina with addition of $\operatorname{CTABr}(1,3,5 \mathrm{~g})$ shows that main content of mesoporous alumina consist of Alumina $\left(\mathrm{Al}_{2} \mathrm{O}_{3}\right)$, even thought was found of bromide at lowest percentages. The amount of alumina in this synthesis was quite a lot (97.46-98.36 wt.\%), it indicated that extraction of alumina from red mud was succeed by adding of $\mathrm{CTABr}$ as template [21]. The percentage of this component are shown at Table 2.

\section{$\mathrm{N}_{2}$ Adsorption-Desorption}

Specific surface area, particle size distribution and the total of pore volume can be analyzed by $\mathrm{N}_{2}$ adsorption-desorption characterization. The specific surface area was determined by BET (SBET) method whereas pore size was determined by BJH method. Fig. 4 showed isotherms adsorption characteristics of the synthesized materials with addition of $\mathrm{CTABr}(1,3$, $5 \mathrm{~g})$. These results showed that each synthesized materials have similarities pattern. The sorption isotherms demonstrate the typical type IV (BrunauerDeming-Deming-Teller (BDDT) Classification). Gas adsorption was occur at low relative pressure $\left(P / P_{0}<0.3\right)$

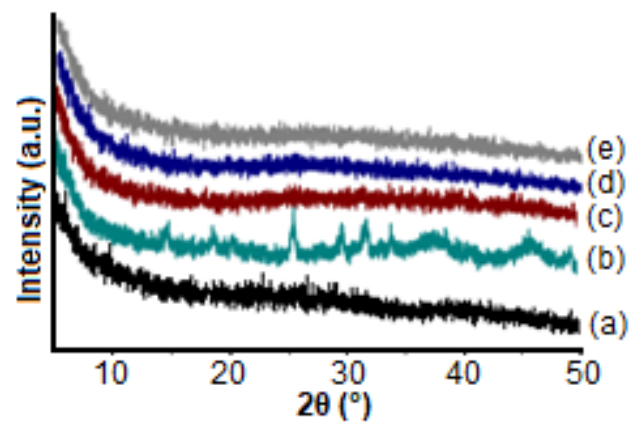

Fig 2. XRD pattern for (a) Al-salt (alumina salt), (b) $\mathrm{y}$ $\mathrm{Al}_{2} \mathrm{O}_{3}$, (c) AMC1, (d) AMC3, (e) AMC5, which C1, C3, C5 are $7.5 \mathrm{~g}$ alumina salt added CTABr: 1, 3, $5 \mathrm{~g}$, respectively
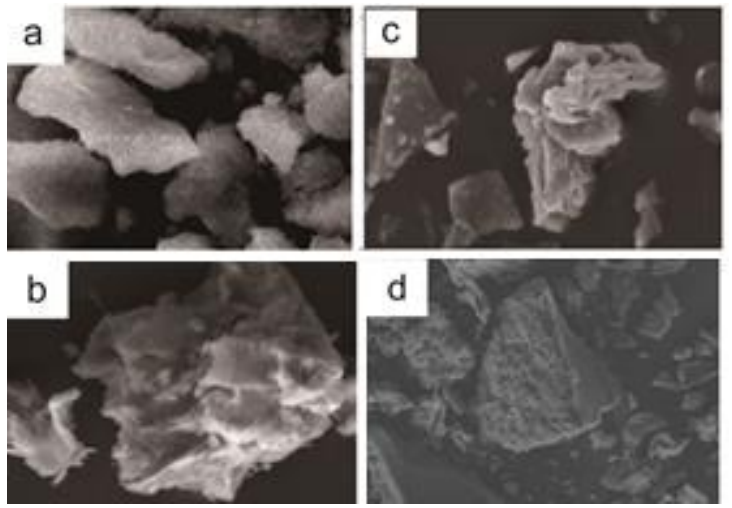

Fig 3. SEM images and EDX spectra for (a) Al-salt (alumina salt), (b) AMC1, (c) AMC3, (d) AMC5, which $\mathrm{C} 1, \mathrm{C} 3, \mathrm{C} 5$ are $7.5 \mathrm{~g}$ alumina salt added CTABr: 1, 3, 5 $\mathrm{g}$, respectively

Table 2. Chemical composition (contents-wt.\%) of alumina salt and mesoporous alumina

\begin{tabular}{llllll}
\hline Sample & $\mathrm{Fe}_{2} \mathrm{O}_{3}$ & $\mathrm{Al}_{2} \mathrm{O}_{3}$ & $\mathrm{SiO}_{2}$ & $\mathrm{Cl}$ & $\mathrm{Br}$ \\
\hline Alumina Salt & 0.82 & 52.89 & 0.3 & 38.8 & 0.6 \\
AMC1 & 0.56 & 97.55 & 0.67 & - & 1.20 \\
AMC3 & 0.35 & 97.46 & 0.53 & - & 1.64 \\
AMC5 & 0.49 & 98.36 & 0.05 & - & 1.11 \\
\hline
\end{tabular}




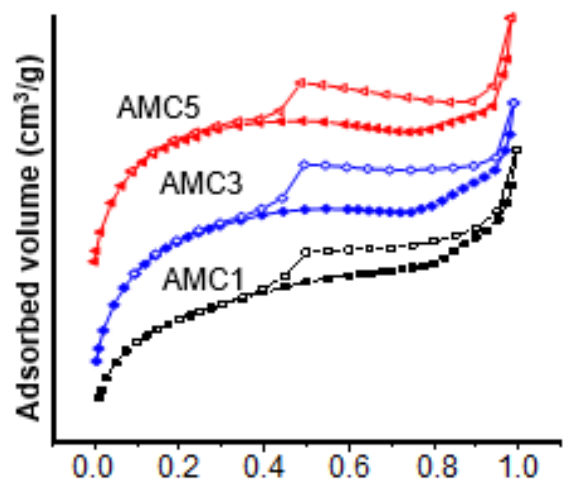

Fig 4. $\mathrm{N}_{2}$ adsorption/desorption isotherms of alumina mesoporous with addition of $1,3,5 \mathrm{~g} \mathrm{CTABr}$, respectively

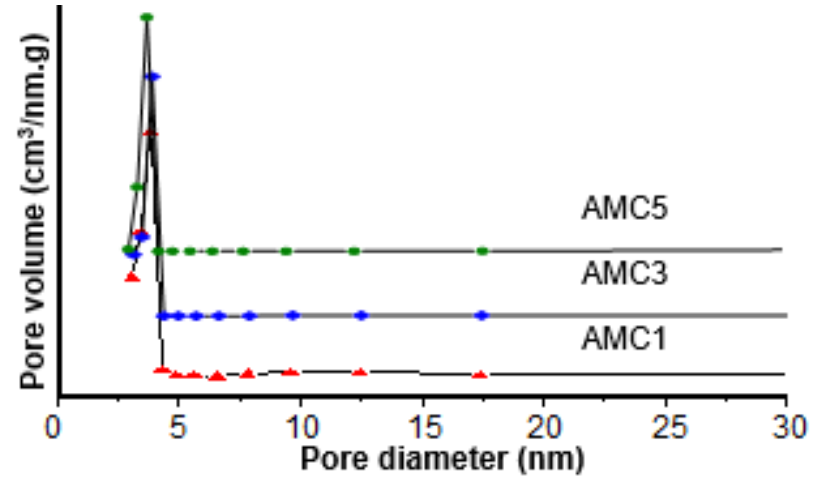

Fig 5. Pore size distribution of alumina mesoporous with added 1, 3, $5 \mathrm{~g} \mathrm{CTABr}$, respectively

Table 3. Textural of amorphous mesoporous alumina from red mud

\begin{tabular}{|c|c|c|c|c|c|}
\hline Sample name & $\begin{array}{l}\text { Weight ratio } \\
\text { CTABr/alumina salt }\end{array}$ & $\begin{array}{l}\mathrm{SBET}^{\mathrm{a}} \\
\left(\mathrm{m}^{2} \mathrm{~g}^{-1}\right)\end{array}$ & $\begin{array}{l}\text { Smeso } \\
\left(m^{2} g^{-1}\right)\end{array}$ & $\begin{array}{l}V_{\text {meso }}{ }^{c} \\
\left(m^{3} g^{-1}\right)\end{array}$ & $\begin{array}{l}D_{\text {meso }}{ }^{d} \\
(\mathrm{~nm})\end{array}$ \\
\hline AMC1 & 1.57 & 241 & 61.45 & 0.11 & 3.82 \\
\hline AMC3 & 4.71 & 223 & 37.65 & 0.06 & 3.82 \\
\hline AMC5 & 7.85 & 216 & 24.72 & 0.05 & 3.81 \\
\hline $\begin{array}{ll}\mathrm{S}_{\mathrm{BET}} & \text { (Tota } \\
\mathrm{S}_{\text {meso }} & \text { (mes } \\
\mathrm{V}_{\text {meso }} \text { (mes }\end{array}$ & $\begin{array}{l}\text { rea) by BET method } \\
\text { ace areas) by BJH m } \\
\text { me) by BJH method }\end{array}$ & & & & \\
\hline
\end{tabular}

showed monolayer. Synthesized materials have H2-type hysteresis loop at relative pressure $\left(P / P_{0} \quad 0.45-0.92\right)$ which implying nonunformity of pore opening associated with pore constrictions and or ink bottle pores with narrow necks and wide bodies, which are formed between primary crystallite within the 2D nanosheets or nanoplates [22]. Then the high relative pressure part of the hysteresis loop $(0.92<\mathrm{p} / \mathrm{p} 0<1.00)$ belongs to H3type related to slit-like pores, suggesting the textural large pores formed between secondary particles due to aggregation of nano-flakes for the hierarchical porous super structures [23].

Shown in Fig. 5 are the pore size distributions (PSD) obtained from the nitrogen adsorption isotherms displayed in Fig. 4. PSD curve of all synthesized materials covers similarities pattern with narrow pore size distribution which are around $3.2 \mathrm{~nm}$. It indicated that, the porous materials contain dominant mesopores (2-50 nm). Table 3 shows pore size distribution, pore volume, mesoporous volume from mesoporous alumina. Pores were formed after Increasing CTABr concentration influence of pore size distribution, pore volume, mesoporous volume. In this research, increasing weight ratio $\mathrm{CTABr} / \mathrm{Al}$-salt in range $1.57-7.85$ result decresed surface area. This result showed that additon of $\mathrm{CTABr}$ didn't influence of pore size distribution but influence pore volume and surface area. In this research used CTABr/Al-Salt in range 1.57-7.85 showed that surface

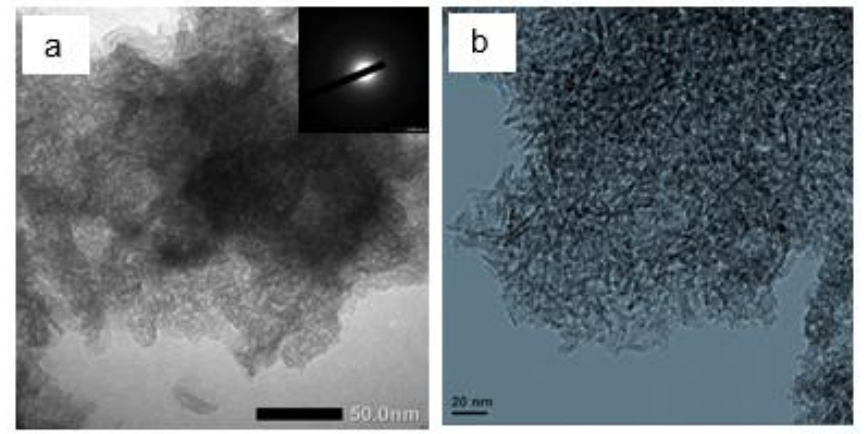

Fig 6. TEM images of synthesized materials (a) with 3 g CTABr (AMC3) (b) $\left(\mathrm{MA}_{(400)}\right)$ Han et al. [25]

area be decrease from 261 be $241 \mathrm{~m}^{2} / \mathrm{g}$. It is because increasing density molecule on mesoporous alumina caused close distance between molecule lattice [24].

\section{TEM Analysis}

The TEM analysis on the synthesized material at weight ratio $\mathrm{CTABr} / \mathrm{Al}$-salt 4.71 revealed the morphology of the mesoporous alumina. Fig. 6 Shows two representative TEM images of mesoporous alumina. TEM images of AMC3 sample (from this study) shows disordered phase of mesoporous alumina (Fig. 6(a)), which is similar to $\mathrm{MA}_{(400)}$ sample (Fig. 6(b)) as mesoporous alumina from Han et al. [25] study with 
addition of pluronic $\mathrm{P}-123$ as mesoporous directing agent. This result is supported by XRD pattern that mesoporous alumina have amorphous phase.

\section{CONCLUSION}

This study reported that synthesis of mesoporous alumina from red mud using sol-gel method previously was done by magnetic separation method and extraction of alumina from red mud. The content of alumina in red mud was $28.88 \%$. This material was used as a main source for synthesis of mesoporous alumina with addition of $\mathrm{CTABr}$ as template. The result from XRF, XRD, $\mathrm{N}_{2}$ adsorption-desorption and SEM-EDX showed that mesoporous alumina was succesfully synthesized from red mud. The effect of weight ratio $\mathrm{CTABr} / \mathrm{Al}$-salt in range 1.57-7.85 influenced surface area and pore volume but didn't influence of the pore size distribution. The largest surface area and pore volume were collected in ratio CTABr/Al-salt 1.57 i.e. $241 \mathrm{~m}^{2} / \mathrm{g}$ and $0.11 \mathrm{~cm}^{3} / \mathrm{g}$, respectively.

\section{ACKNOWLEDGEMENT}

The authors would like to acknowledge the Ministry of Research and Higher Education, Indonesia, under "PUPT" research grant No. 003246.18/IT2.11/PN.08/ 2015-2017.

\section{REFERENCES}

[1] Zhang, R., Zheng, S., Ma, S., and Zhang, Y., 2011, Recovery of alumina and alkali in Bayer red mud by the formation of andradite-grossular hydrogarnet in hydrothermal process, J. Hazard. Mater., 189 (3), 827-835.

[2] Wang, J., and Zhao, P., 2013, Method of dealkalizing red mud and recovering aluminium and iron, Google Patents, CN 201210573146.

[3] Liu, Y., Lin, C., and Wu, Y., 2007, Characterization of red mud derivated from a combined Bayer process and bauxite calcinations method, J. Hazard. Mater., 146 (1-2), 255-261.

[4] Mayes, W.M., Jarvis, A.P., Burke, I.T., Walton, M., Feigl, V.R., Klebercz, O., and Gruiz, K., 2011, Dispersal and attenuation of trace contaminants downstream of the Ajka bauxite residue (red mud) depository failure, Hungary, Environ. Sci. Technol., 45 (12), 5147-5155.

[5] Liu, Y., Naidu, R., and Ming, H., 2013, Surface electrochemical properties of red mud (bauxite residue): Zeta potential and surface charge density, J. Colloid Interface Sci., 394, 451-457.

[6] Klauber, C., Gräfe, M., and Power, G., 2011, Bauxite residue issues: II. Options for residue utilization, Hydrometallurgy, 108 (1-2), 11-32.
[7] Liu, W., Yang, J., and Xiao, B., 2009, Review on treatment and utilization of bauxite residues in China, Int. J. Miner. Process., 93 (3-4), 220-231.

[8] Man, K., Zhu, Q., Li, L., Liu, C., and Xing, P., 2017, Preparation and performance of ceramic filter material by recovered silicon dioxide as major leached components from red mud, Ceram. Int., 43 (10), 7565-7572.

[9] Li, J., Xu, L., Sun, P., Zhai, P., Chen, X., Zhang, H., Zhang, Z., and Zhu, W., 2017, Novel application of red mud: Facile hydrothermalthermal conversion synthesis of hierarchical porous $\mathrm{AlOOH}$ and $\mathrm{Al}_{2} \mathrm{O}_{3}$ microspheres as adsorbents for dye removal, Chem. Eng. J., 321, 622-634.

[10] Paramguru, R.K., Rath, P.C., and Misra, V.N., 2004, Trend in red mud utilization - A review, Miner. Process. Extr. Metall. Rev., 26 (1), 1-29.

[11] Snars, K., and Gilkes, R.J., 2009, Evaluation of bauxite residues (red mud) of different origins for environmental application, Appl. Clay Sci., 46 (1), 13-20.

[12] Wang, S., Ang, H.M., and Tade, M.O., 2008, Novel applications of red mud as coagulant, adsorbent and catalyst for environmentally benign process, Chemosphere, 72 (11), 1621-1635.

[13] Ray, S., Wasewar, K.L., Lataye, D.H., Mukhopadhyay, J., and Yoo, C.K., 2013, Feasibility of red mud neutralization with seawater using Taguchi's methodology, Int. J. Environ. Sci. Technol., 10 (2), 305-314.

[14] Samal, S., Ray, A.K., and Bandopadhyay, A., 2013, Proposal for resources, utilization and processes of red mud in India - A review, Int. J. Miner. Process., 118, 43-55.

[15] Hammond, K., Apelian, B.M.D., and Blanpain, B., 2013, CR3 communication: red mud-a resource or a waste?, JOM, 65, 340-341.

[16] Vachon, P., Tyagi, R.D., Auclair, J.C., and Wilkison, K.J., 1994, Chemical and biological leaching of aluminium from red mud, Environ. Sci. Technol., 28 (1), 26-30.

[17] Liang, W., Couperthwaite, S.J., Kaur, G., Yan, C., Johnstone, C., and Millar, G,J., 2014, Effect of strong acids on red mud structural and fluoride adsorption properties, J. Colloid and Interface Sci., 423, 158-165.

[18] Kwon, S.K., Kimijama, K., Kanie, K., Muramatsu, A., Suzuki, S., Matsubara, E., and Waseda, Y., 2005, Effect of silicate ions on conversion of ferric hydroxideto $\beta-\mathrm{FeOOH}$ and $\alpha-\mathrm{Fe}_{2} \mathrm{O}_{3}$, Mater. Trans., 46 (2), 155-158.

[19] Cava, S., Tebcherani, S.M., Souza, I.A., Pianaro, S.A., Paskocimas, C.A., Longo, E., and Varela, J.A., 2007, Structural characterization of phase 
transition of $\mathrm{Al}_{2} \mathrm{O}_{3}$ nanopowders obtained by polymeric precursor method, Mater. Chem. Phys., 103 (2-3), 394-399.

[20] Pan, F., Lu, X., Wang, T., Wang, Y., Zhang, Z., Yan, Y., and Yang, S., 2013, Synthesis of largemesoporous $\mathrm{Y}-\mathrm{Al}_{2} \mathrm{O}_{3}$ from coals series kaolin at room temperature, Mater. Lett., 91, 136-138.

[21] Yue, M.B., Xue, T., Jiao, W.Q., Wang, Y.M., and He, M.Y., 2011, CTAB-directed synthesis of mesoporous $Y$-alumina promoted by hydroxyl carboxylate: The interplay of tartrate and CTAB, Solid State Sci., 13 (2), 409-416.

[22] Chen, R., Yu, J., and Xiao, W., 2013, Hierarchically porous $\mathrm{MnO}_{2}$ microspheres with enhanced adsorption performance, J. Mater. Chem. A, 38, 11682-11690.
[23] Zhang, Z., Zhang, H., Zhu, L., Zhang, Q., and Zhu, W., 2016, Hierarchical porous $\mathrm{Ca}\left(\mathrm{BO}_{2}\right)_{2}$ microspheres: Hydrothermal-thermal conversion synthesis and their applications in heavy metals ions adsorption and solvent-free oxidation of benzyl alcohol, Chem. Eng. J., 283, 1273-1284.

[24] Kim, J.H., Jung, K.Y., Park, K.Y., and Cho, S.B., 2010, Characterization of mesoporous alumina particles prepared by spray pyrolysis of $\mathrm{Al}\left(\mathrm{NO}_{3}\right)_{2} \cdot 9 \mathrm{H}_{2} \mathrm{O}$ precursor: Effect of CTAB and urea, Microporous Mesoporous Mater., 128 (1-3), 85-90.

[25] Han, C., Li, H., Pu, H., Yu, H., Deng, L., Huang, S., and Luo, Y., 2013, Synthesis and characterization of mesoporous alumina and their performances for removing arsenic $(\mathrm{V})$, Chem. Eng. J., 217, 1-9. 